\title{
GCU
}

Glasgow Caledonian

University

University for the Common Good

\section{Indoor Characterization of Genetically Optimized Circular Rotational Square Hyperboloid (GOCRSH) Concentrator}

Freier Raine, Daria; Muhammad-Sukki, Firdaus; Ramirez-Iniguez, Roberto; Jafry, Tahseen; Ardila-Rey, Jorge Alfredo; Gamio, Carlos

Published in:

2020 47th IEEE Photovoltaic Specialists Conference (PVSC)

DOI:

10.1109/PVSC45281.2020.9300920

Publication date:

2021

Document Version

Author accepted manuscript

Link to publication in ResearchOnline

Citation for published version (Harvard):

Freier Raine, D, Muhammad-Sukki, F, Ramirez-Iniquez, R, Jafry, T, Ardila-Rey, JA \& Gamio, C 2021, Indoor Characterization of Genetically Optimized Circular Rotational Square Hyperboloid (GOCRSH) Concentrator. in 2020 47th IEEE Photovoltaic Specialists Conference (PVSC)., 9300920, IEEE, pp. 2600-2604, 47th IEEE Photovoltaic Specialists Conference, 15/06/20. https://doi.org/10.1109/PVSC45281.2020.9300920

\section{General rights}

Copyright and moral rights for the publications made accessible in the public portal are retained by the authors and/or other copyright owners and it is a condition of accessing publications that users recognise and abide by the legal requirements associated with these rights.

Take down policy

If you believe that this document breaches copyright please view our takedown policy at https://edshare.gcu.ac.uk/id/eprint/5179 for details of how to contact us. 


\section{GCU}

Glasgow Caledonian

University

University for the Common Good

\section{Indoor characterization of genetically optimised circular rotating square hyperboloid (GOCRSH) concentrator}

Freier Raine, Daria; Muhammad-Sukki, Firdaus; Ramirez-Iniguez, Roberto; Jafry, Tahseen; Ardila-Rey, Jorge Alfredo; Gamio, Carlos

Published in:

2020 47th IEEE Photovoltaic Specialists Conference (PVSC)

DOI:

10.1109/PVSC45281.2020.9300920

Publication date:

2021

Document Version

Peer reviewed version

Link to publication in ResearchOnline

Citation for published version (Harvard):

Freier Raine, D, Muhammad-Sukki, F, Ramirez-Iniguez, R, Jafry, T, Ardila-Rey, JA \& Gamio, C 2021, Indoor characterization of genetically optimised circular rotating square hyperboloid (GOCRSH) concentrator. in 2020 47th IEEE Photovoltaic Specialists Conference (PVSC). IEEE, pp. 2600-2604, 47th IEEE Photovoltaic Specialists Conference, 15/06/20. https://doi.org/10.1109/PVSC45281.2020.9300920

\section{General rights}

Copyright and moral rights for the publications made accessible in the public portal are retained by the authors and/or other copyright owners and it is a condition of accessing publications that users recognise and abide by the legal requirements associated with these rights.

Take down policy

If you believe that this document breaches copyright please view our takedown policy at https://edshare.gcu.ac.uk/id/eprint/5179 for details of how to contact us. 


\section{Indoor Characterization of Genetically Optimized Circular Rotational Square Hyperboloid (GOCRSH) Concentrator}

\author{
Daria Freier Raine \\ School of Computing, \\ Engineering and Built \\ Environment \\ Glasgow Caledonian University \\ Glasgow, UK \\ daria_freier@outlook.de
}

\author{
Firdaus Muhammad-Sukki \\ School of Engineering, \\ Robert Gordon University \\ Aberdeen, UK \\ f.b.muhammad-sukki@rgu.ac.uk
}

Jorge Alfredo Ardila-Rey

Department of Electrical Engineering

Universidad Técnica Federico

Santa María

Santiago de Chile, Chile

jorge.ardila@usm.cl

\begin{abstract}
This paper evaluates the performance of a genetically optimized circular rotational square hyperboloid (GOCRSH) concentrator for low-concentrating photovoltaic (PV) application. The experimental analysis of 4 types of GOCRSH namely the GOCRSH_A GOCRSH_B, GOCRSH_Crh and GOCRSH_D, were tested indoor under standard text conditions of $1000 \mathrm{~W} / \mathrm{m}^{2}, A M 1.5 \mathrm{G}$ and at the temperature of $25^{\circ} \mathrm{C}$. From the indoor experiments, it was found that the prototypes were showing the maximum power point ratio under normal incidence of $2.9 x$, 2.6x, 3.9x and 2.7x with the GOCRSH_A GOCRSH_B, GOCRSH_Crh and GOCRSH_D respectively.
\end{abstract}

Keywords - genetically optimized circular rotational square hyperboloid concentrator, solar photovoltaic, indoor characterization, opto-electronic gain.

\section{INTRODUCTION}

The world is battling the COVID-19 pandemic that has caused a lot of disruptions and the healthcare systems are struggling to cope especially in developing countries. Energy services are vital to inhibiting the pandemic - from electrifying the healthcare facilities, providing the clean water for sanitation to facilitating communications and IT services that link people while keeping social distancing [1]. However, electrical energy access is a problem in sub-Saharan Africa. The statistic shows that approximately only $28 \%$ of healthcare facilities have access to reliable electricity, which is very disturbing [1].

Nonetheless, these sub-Saharan countries are blessed with untapped solar energy has the potential to power these healthcare facilities [2], [3], through the use of solar photovoltaic (PV) system. Although there is declining cost of solar PV around the globe, the cost is still considered expensive especially in developing countries [4]. Silicon-wafer based PV technology accounted for about $95 \%$ of the total production in 2017 [5] and their production is very energy intensive leading to

The authors would like to thank Glasgow Caledonian University for funding the research, and the Agencia Nacional de Investigación y Desarrollo (through the project Fondecyt regular 1200055 and the project Fondef ID19I10165) and project PI_m_19_01 (UTFSM) for funding the conference fee.

\author{
Roberto-Ramirez-Iniguez \\ School of Computing, \\ Engineering and Built \\ Environment \\ Glasgow Caledonian University \\ Glasgow, UK \\ rra4@gcu.ac.uk \\ Carlos Gamio \\ School of Computing, \\ Engineering and Built \\ Environment \\ Glasgow Caledonian University \\ Glasgow, UK \\ carlos.gamio@gcu.ac.uk
}

increased greenhouse gas (GHG) emissions [6] and involves the use of toxic substances which have the potential to harm workers and the environment [7], [8]. It has been shown that the this impact on the environment can be lessened by substituting part of the PV material with solar PV concentrators [9]. By focusing light from a large area onto a small area, a solar PV concentrator increases the power output of the PV cell, hence less PV material is required [10]. One of such concentrator designs is the circular rotational square hyperboloid (CRSH) [11].

Recently, the CRSH was optimized using genetic algorithms, and the new design is known as genetically optimized circular rotational square hyperboloid (GOCRSH) concentrator [12]. The optimization allows for several advantages including: (i) a more compact concentrator design; (ii) it is easy to use; (iii) has an optical concentration ratio of around $3 \mathrm{x}$, and wide half-acceptance angles of $\pm 40^{\circ}$ which enables it to capture light for more than 5 hours without tracking.

The aim of this paper is to present the characterization of the GOCRSH concentrators indoor under standard test conditions (STC). The chosen concentrators are GOCRSH_A, GOCRSH_B, GOCRSH_Crh and GOCRSH_D (see Fig. 1). The detailed characteristics of these concentrators are presented in Table I.

The GOCRSH prototypes were CNC machined from transparent polymethyl methacrylate (PMMA) since it is more cost effective for prototyping than injection moulding [13]. The GOCRSH prototypes were machined and hand-polished by Dongguan Bole RP\&M Co Ltd. The PV cells were of the laser grooved buried contact (LGBC) type. They were provided by Solar Capture Ltd. These cells are designed for concentrating PV (CPV) applications with concentration ratios below 10x. The measured size of the solar cell size is $100 \mathrm{~mm}^{2}$ including the area allocated for the front contact. A cell efficiency of only $10 \%$ was therefore determined experimentally under STC conditions. 
TABLE I. CHARACTERISTICS OF THE CHOSEN GOCRSH DESIGNS

\begin{tabular}{lcccc}
\hline Lens & GOCRSH_A & GOCRSH_B & GOCRSH_C & GOCRSH_D \\
\hline Volume $V$ in $\mathrm{mm}^{3}$ & 2696 & 2285 & 3796 & 3079 \\
Optical concentration gain $C_{\text {opt } \pm 40^{\circ}}$ & 2.91 & 2.75 & 3.36 & 3.01 \\
Total height $h_{T}$ in mm & 12.74 & 11.74 & 16.64 & 13.16 \\
Entrance aperture diameter $\boldsymbol{d}_{E}$ in mm & 21.79 & 20.62 & 22.01 & 22.77 \\
Geometrical Concentration gain $C_{g}$ & 3.73 & 3.34 & 3.80 & 4.07 \\
Optical efficiency $\eta_{\text {opt } \pm 40^{\circ}}$ & 0.77 & 0.81 & 0.88 & 0.73 \\
\hline
\end{tabular}

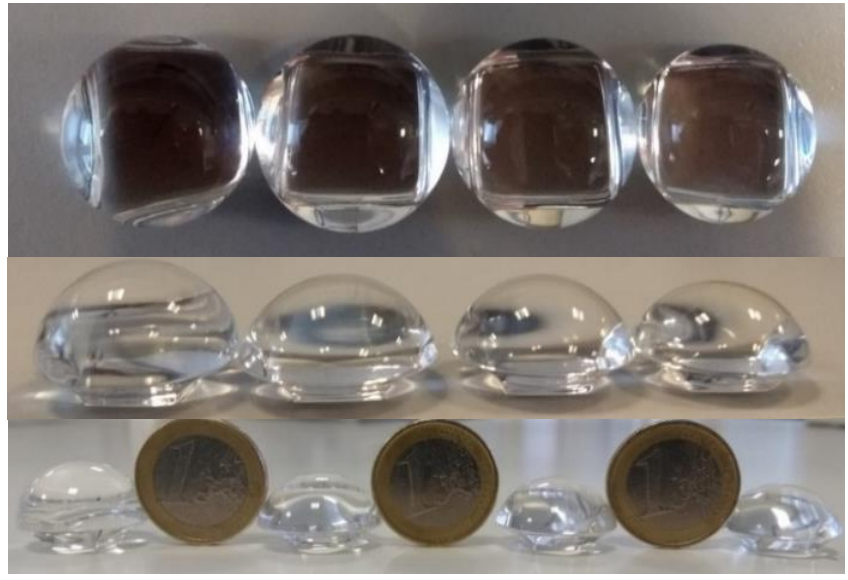

Fig.1. Prototypes of the GOCRSH_C rh $_{\text {rh }}$ GOCRSH_D, GOCRSH_A and GOCRSH_B

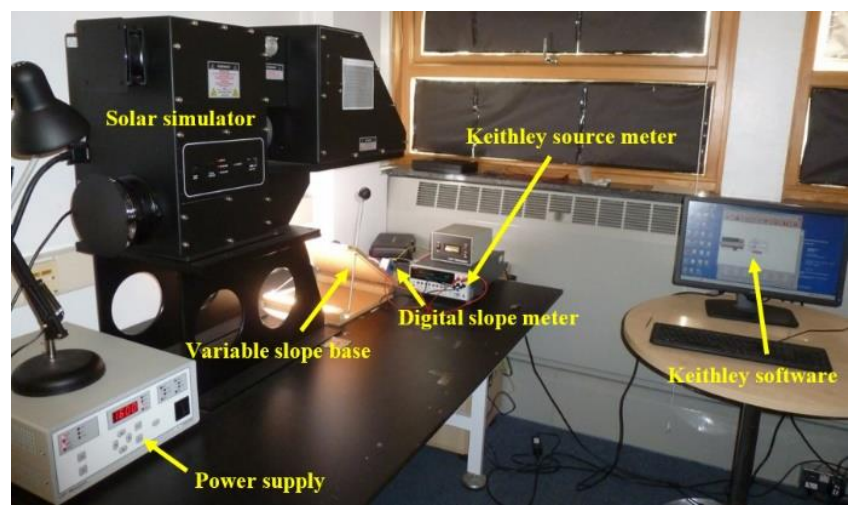

Fig.2. Indoor experimental setup

The concentrated devices and the reference cell were characterized at normal incidence $\left(0^{\circ}\right.$ inclination), obtaining the current-voltage (I-V) and power-voltage (P-V) curves. Furthermore, the angular response of the concentrators was obtained at the angles of incidence between $0^{\circ}$ and $70^{\circ}$ at incremental steps of $5^{\circ}$. Mismatches between the simulation results and the experimental results were determined and possible manufacturing errors leading to the mismatch were discussed.

\section{EXPERIMENTAL SETUP}

The experimental analysis was carried out indoors under an Oriel ${ }^{\circledR}$ Sol3 $A^{\mathrm{TM}}$ Class AAA solar simulator. The xenon short arc lamp of an AAA class solar simulator is ozone free and has a spectral performance match between 0.75 to 1.25 times of a $5800 \mathrm{~K}$ blackbody. Both the temporal instability and the nonuniformity of the irradiance are lower than $2 \%$ within a $200 \mathrm{~mm}$ x $200 \mathrm{~mm}$ footprint at a working distance of $365-395 \mathrm{~mm}$. The irradiance is adjustable between 0.1 and 1 suns where 1 sun equals to $1000 \mathrm{~W} / \mathrm{m}^{2}$. Furthermore, a $1.5 \mathrm{AM}$ filter is integrated to enable STC experimental conditions [14], [15].

The experiment setup is shown in Fig. 2. A SourceMeter instrument from Keithley Instruments (model 2440 5A) was used in combination with the Keithley LabTracer 2.0 software for I-V curve tracing. The SourceMeter is a highly stable multimeter which can function either as a voltage/current source or a voltage/current/resistance meter. The SourceMeter transmits 1700 readings per second and the readings are taken using a four-wire set up which is more accurate than a two-wire set up. The irradiance of the solar simulator was set to 1000 $\mathrm{W} / \mathrm{m}^{2}$ according to STC and was controlled during the experiment with an Oriel PV Reference Cell System (model $91150 \mathrm{~V}$ ). The reference cell consists of a $400 \mathrm{~mm}^{2}$ mono-c-Si solar cell and a type $\mathrm{K}$ thermocouple. Thus, the sun irradiance and the cell temperature could be measured simultaneously. When not placed under the solar simulator, the reference cell can be used to measure the room temperature.

\section{RESULTS AND DISCUSSION}

\section{A. Characterisation of the GOCRSH at $0^{\circ}$ inclination}

$\mathrm{I}-\mathrm{V}$ and $\mathrm{P}-\mathrm{V}$ curves were traced at $0^{\circ}$ inclination to show the difference in short-circuit current $I_{s c}$, open-circuit voltage $V_{o c}$ and maximum power point $\left(\mathrm{P}_{\mathrm{MPP}}\right)$ of the GOCRSH concentrator. The I-V curve tracer was set to sweep the voltage from $0.1 \mathrm{~V}$ to $1 \mathrm{~V}$ to provide the I-V curve of the cell consisting of 100 points. The I-V curves of the concentrated cells and the reference cell are shown in Fig. 3 and the P-V curves in Fig. 4.

Since the measurements were taken at normal incidence $\left(0^{\circ}\right.$ inclination), the difference in $C_{\text {opt }}$ values between GOCRSH_A, GOCRSH_B, GOCRSH_D and the concentrator GOCRSH_Crh is larger than the difference in the averaged $C_{o p t}$ $\pm 40^{\circ}$ values. The power factor and thus the increase in cell efficiency is as high as 3.9x times for the GOCRSH_Crh and $2.9 \mathrm{x}, 2.6 \mathrm{x}$ and $2.7 \mathrm{x}$ for the concentrators GOCRSH_A, GOCRSH_B and GOCRSH_D respectively. The power factor is greater than the $I_{s c}$ factor since it also includes the logarithmically proportional increase in $V$ [16].

The $C_{\text {opt-el }}$ of the GOCRSH concentrators at normal incidence $\left(0^{\circ}\right.$ inclination) were calculated and are compared to the $C_{\text {opt }}$ obtained from simulations in Table III. It can be observed that the experimentally determined $C_{\text {opt-el }}$ is distinctively lower than the $C_{o p t}$, showing an error greater than $10 \%$ for the GOCRSH_A, GOCRSH_B and GOCRSH_D and 
TABLE II. COMPARISON OF THE SIMULATED COPT_0 $0^{\circ}$ AND THE EXPERIMENTALLY OBTAINED COPT-EL_ $0^{\circ}$ AT $0^{\circ}$ INCLINATION

\begin{tabular}{lcccc}
\hline & GOCRSH_A & GOCRSH_B & GOCRSH_C & GOCRSH_D \\
\hline Optical concentration gain $C_{\text {op } \_0^{\circ}}$ & 2.90 & 2.75 & 3.39 & 3.05 \\
Opto-electronic gain $C_{\text {opt-el_0 }}$ & 2.51 & 2.40 & 3.22 & 2.45 \\
\hline Error in \% & $\mathbf{1 3 . 5}$ & $\mathbf{1 2 . 7}$ & $\mathbf{5 . 0}$ & $\mathbf{1 6 . 7}$ \\
\hline
\end{tabular}

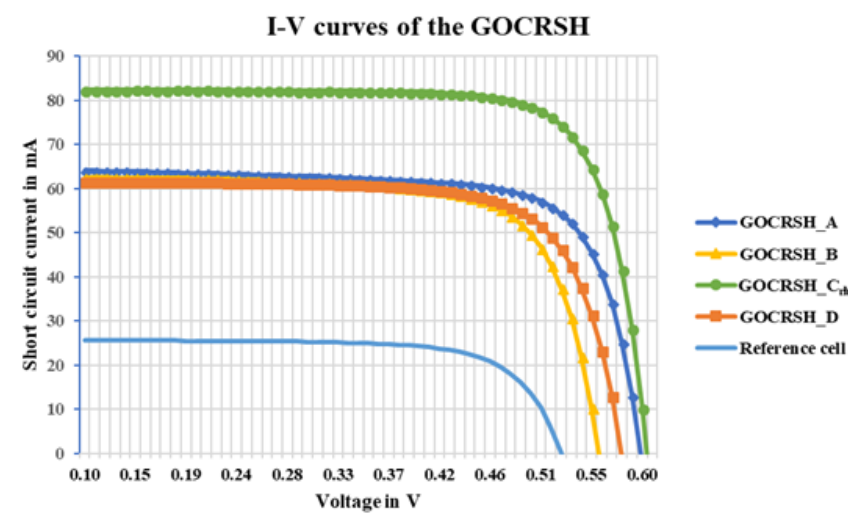

Fig 3. I-V curves of the GOCRSH under STC conditions at normal incidence

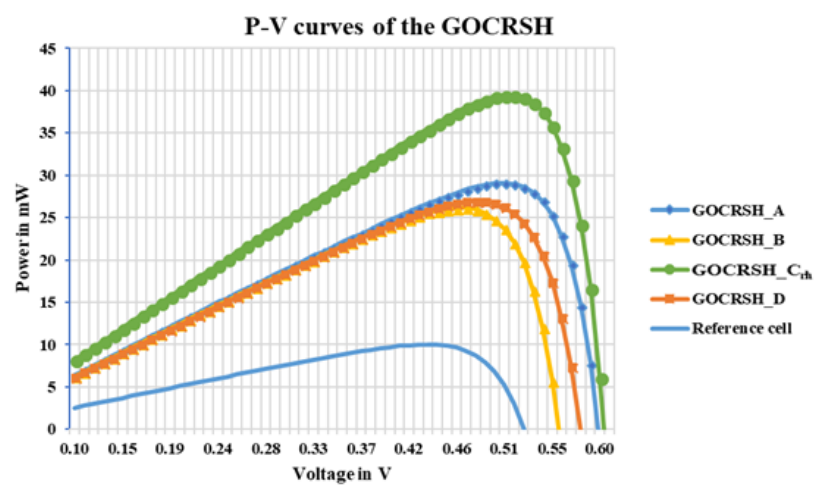

Fig. 4. P-V curves of the GOCRSH under STC conditions at normal incidence

an error smaller than 5\% for the GOCRSH_Crh. Before discussing the possible reasons for the obtained errors, the simulated and experimentally obtained angular response are compared in the following section.

\section{B. Angular response of the GOCRSH}

To determine the angular acceptance of the GOCRSH, the $\mathrm{I}-\mathrm{V}$ curves of the prototypes and the reference cell were measured at angles of incidence between $0^{\circ}$ and $70^{\circ}$ at incremental steps of $5^{\circ}$ and the results were mirrored to represent the angular acceptance as shown in Figs. 5-8. A variable slope was used to tilt the device and the inclination was measured by a digital tilt meter. The irradiance was set to 1000 $\mathrm{W} / \mathrm{m}^{2}$ and the room temperature was maintained at $25^{\circ} \mathrm{C}$.

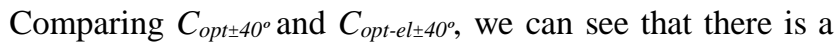
high mismatch for the concentrators GOCSRH_A, GOCSRH_B and GOCSRH_D (Table III). While manufacturing errors were expected to lead to a lower $C_{o p t-e l \pm 40^{\circ}}$ compared to $C_{o p t \pm 40^{\circ}}$, a mismatch of $9 \%$ and greater is not within the expected norm. This is possibly due to prototype manufacturing, device assembly and experiment errors. Since the GOCRSH_C $\mathrm{C}_{\mathrm{rh}}$ has by far the smallest error between $C_{o p t-e l \pm 40^{\circ}}$ and $C_{o p t \pm 40^{\circ}}$, the main error must be due to the reflection caused by the entrapped material on the solar cell. When seen from the top, the bubbles are transparent and show reflective behaviour at certain angles. It is therefore assumed that the reflections are entrapped air bubbles, however, the pattern of the bubbles gives the impression of a brushed liquid. In fact, the primer on the GOCRSH_A, GOCSRH_B and GOCRSH_D cells was left to dry longer than on the GOCRSH_C Ch $_{\text {rh }}$ The primer left to dry too long might have caused the impurities on the GOCRSH_A, GOCSRH_B and GOCRSH_D cells.

A further source of errors is the tilt of the concentrator on the solar cell. This is due to the tabbing wire being positioned on the front and the back contact of the cell at the same cell side. Thus, on one side of the cell, the position of the concentrator is 0.2 $0.3 \mathrm{~mm}$ higher than on the other side. Furthermore, a misalignment of the concentrators on the solar cells leads to ray

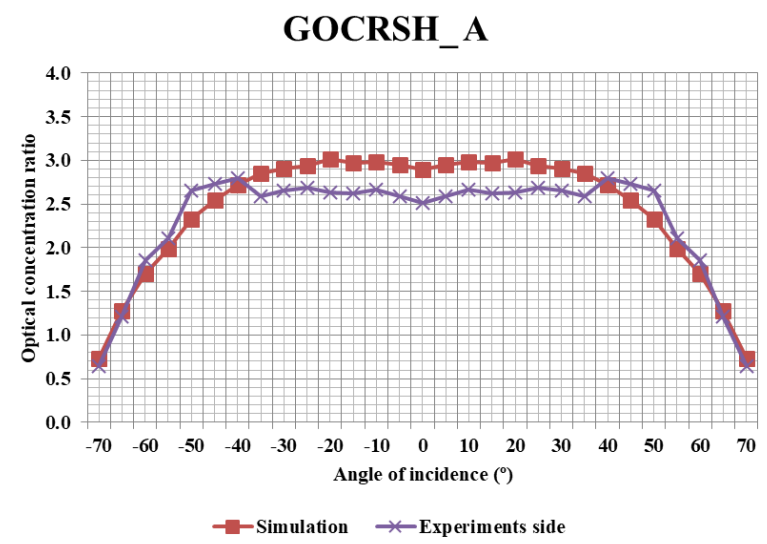

Fig. 5. Experimental and simulated angular acceptance of the GOCRSH_A

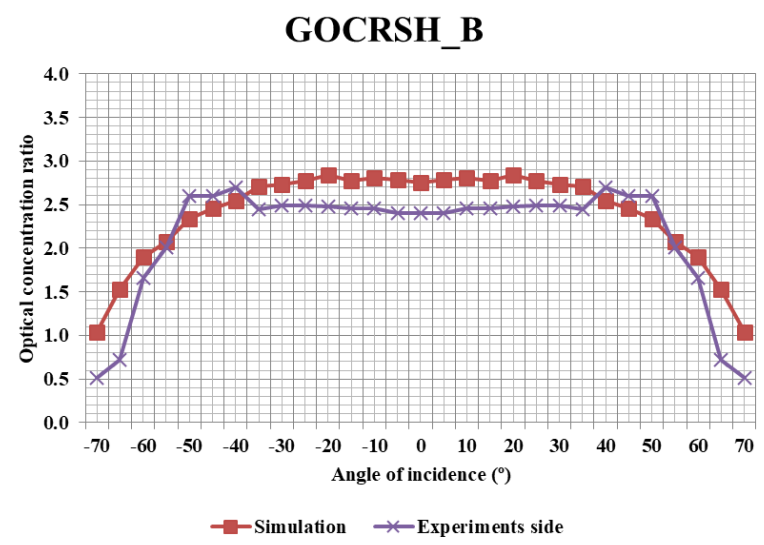

Fig. 6. Experimental and simulated angular acceptance of the GOCRSH_B 
TABLE III. COMPARISON OF THE SIMULATION AND EXPERIMENTAL RESULTS

\begin{tabular}{|c|c|c|c|c|}
\hline & GOCRSH_A & GOCRSH_B & $\mathrm{GOCRSH}_{-} \mathrm{C}_{\mathrm{rh}}$ & GOCRSH_D \\
\hline Optical concentration gain $C_{o p t \pm 40^{\circ}}$ & 2.91 & 2.75 & 3.21 & 3.01 \\
\hline Opto-electronic gain $C_{o p t-e l \pm 40^{\circ}}$ tabbing wire on the side & 2.64 & 2.48 & 3.12 & 2.55 \\
\hline Error in \% & 9.28 & 9.82 & 2.80 & 15.28 \\
\hline
\end{tabular}

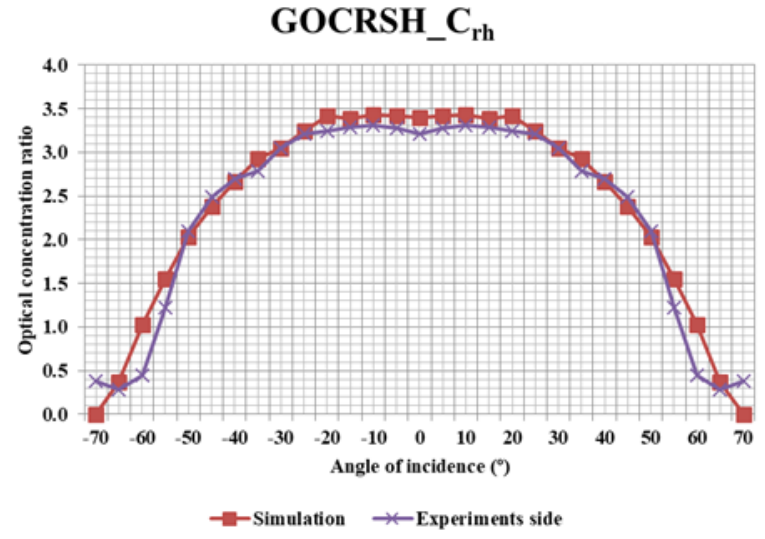

Fig. 7. Experimental and simulated angular acceptance of the GOCRSH_C

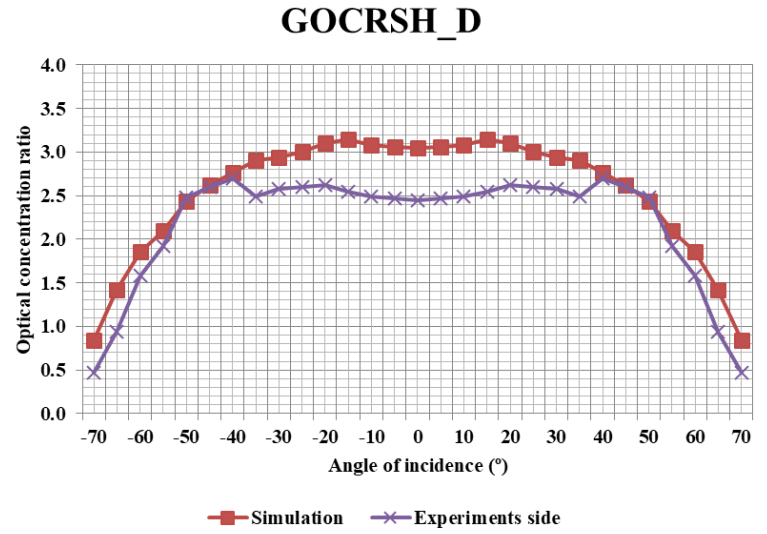

Fig. 8. Experimental and simulated angular acceptance of the GOCRSH_D

losses. While a slight misalignment can be seen with the GOCRSH_C $\mathrm{C}_{\mathrm{rh}}$, less visible misalignments of the other concentrators are possible. Another major source of error is the small size of the active cell area which is smaller than the exit aperture width of the GOCRSH by $10 \%$. Further possible errors include: soldering errors, error in the 3D model created from MATLAB coordinates, error introduced during the $\mathrm{CNC}$ machined and polishing of the prototype, positioning error of the device on the variable slope during the experimental analysis, and precision error of the used measuring devices.

\section{CONCLUSIONS}

In this paper, the experimental analysis of the GOCRSH_A GOCRSH_B, GOCRSH_C $\mathrm{C}_{\mathrm{rh}}$ and GOCRSH_D was carried out. The prototypes were analysed indoors under the solar simulator showing an $P_{M P P}$ ratio under normal incidence of $2.9 \mathrm{x}, 2.6 \mathrm{x}$, 3.9x and 2.7x with the GOCRSH_A GOCRSH_B, GOCRSH_C $\mathrm{rh}$ and GOCRSH_D respectively.

Compared to the $C_{\text {opt_o }} o^{\circ}$ values obtained from simulation analysis, the experimentally determined $C_{\text {opt-el_o }} 0^{\circ}$ showed a reduced concentration ratio by $13.5 \%, 12.7 \%, 5.0 \%$ and $16.7 \%$ for the GOCRSH_A GOCRSH_B, GOCRSH_C $\mathrm{C}_{\mathrm{rh}}$ and GOCRSH_D respectively. Furthermore, the $C_{\text {opt-el }}$ of the GOCRSH was determined at the angles of incidence between $0^{\circ}$ and $70^{\circ}$ at incremental steps of $5^{\circ}$. The mismatch between the average $C_{\text {opt-el } \pm 40^{\circ}}$ and the average $C_{\text {opt } \pm 40^{\circ}}$ was found to be lower than the mismatch between the $C_{\text {opt_ }} 0^{\circ}$ and $C_{\text {opt-el_ }} 0^{\circ}$ values.

The lower $C_{\text {opt-el } \pm 40^{\circ}}$ was identified to be due to several integration errors, including reflective air bubbles on the solar cell, a smaller active area of the cell than the exit aperture of the GOCRSH and the tilt of the concentrators on the cell. Since the GOCRSH_C $\mathrm{C}_{\text {rh }}$ showed the smallest error, the main cause for the high mismatch values was assumed to be due to the entrapped air on the solar cells, which have been observed mainly for the GOCRSH_A GOCRSH_B and GOCRSH_D devices.

\section{REFERENCES}

[1] R. Puliti, "Energy access takes center stage in fighting COVID-19 (Coronavirus) and powering recovery in Africa," The World Bank, 2020. [Online].

Available:

https://www.worldbank.org/en/news/opinion/2020/04/22/energy-

access-critical-to-overcoming-covid-19-in-africa. [Accessed: 04-Jun2020].

[2] J. Amankwah-Amoah, "Solar energy in Sub-Saharan Africa: The challenges and opportunities of technological leapfrogging," Thunderbird Int. Bus. Rev., vol. 57, no. 1, pp. 15-31, Jan. 2015.

[3] A. Abubakar Mas'ud et al., "A review on the recent progress made on solar photovoltaic in selected countries of sub-Saharan Africa," Renew. Sustain. Energy Rev., vol. 62, pp. 441-452, Sep. 2016.

[4] A. Alamoudi et al., "Using static concentrator technology to achieve global energy goal," Sustainability, vol. 11, no. 11, pp. 3056:1-22, May 2019.

[5] Fraunhofer Institute for Solar Energy Systems, "Photovoltaics Report," May 2020.

[6] M. Vellini, M. Gambini, and V. Prattella, "Environmental impacts of PV technology throughout the life cycle: Importance of the end-of-life management for Si-panels and CdTe-panels," Energy, vol. 138, pp. 1099-1111, 2017.

[7] S. Coalition, "Toward a Just and Sustainable Solar Energy Industry," 2009.

[8] D. Mulvaney, "Solar Energy Isn't Always as Green as You Think," IEEE Spectrum, 2014. .

[9] C. Lamnatou, H. Baig, D. Chemisana, and T. K. Mallick, "Environmental assessment of a building-integrated linear dielectricbased concentrating photovoltaic according to multiple life-cycle indicators," J. Clean. Prod., vol. 131, pp. 773-784, 2016.

[10] F. Muhammad-Sukki et al., "Mirror symmetrical dielectric totally internally reflecting concentrator for building integrated photovoltaic systems," Appl. Energy, vol. 113, pp. 32-40, 2014.

[11] D. Freier, R. Ramirez-Iniguez, C. Gamio, T. Jafry, and F. MuhammadSukki, "Novel nonimaging solar concentrator for portable solar systems for developing countries," in 2017 IEEE PES PowerAfrica, 2017, pp. 307-310. 
[12] D. Freier Raine, R. Ramirez-Iniguez, T. Jafry, F. Muhammad-Sukki, and C. Gamio, "Design method of a compact static nonimaging concentrator for portable photovoltaics using parameterisation and numerical optimisation," Appl. Energy, vol. 266, pp. 114821:1-12, May 2020.

[13] S. H. Abu-Bakar, "Novel Rotationally Asymmetrical Solar Concentrator for the Building Integrated Photovoltaic System," PhD Thesis, Glasgow Caledonian University, United Kingdom, 2016.

[14] Newport, "Oriel @ Sol3A ${ }^{\text {TM }}$ Class AAA Solar Simulators," 2018.

[15] M. W. Davidson, "Fundamentals of Xenon Arc Lamps," Education in
Microscopy and Digital Imaging, 2020. [Online]. Available: http://zeisscampus.magnet.fsu.edu/articles/lightsources/xenonarc.html. [Accessed: 04-Jun-2020].

[16] Volker Quaschning, "Entwicklung der weltweiten Kohlendioxidemissionen und -konzentration in der Atmosphäre," 2013. [Online]. Available: http://www.volkerquaschning.de/datserv/CO2/index.php. [Accessed: 24-Oct-2014]. 